\title{
Modulated heat shock protein expression during pathogenic Vibrio alginolyticus stress of sea bream
}

\author{
Eddie E. Deane, Jun Li, Norman Y. S. Woo* \\ Department of Biology, The Chinese University of Hong Kong, Shatin, New Territories, Hong Kong SAR, China
}

\begin{abstract}
The effects of infective Vibrio alginolyticus and its extracellular product (ECP) on host fish function are not well understood. In this study a partial biochemical characterization of the ECP from an infective strain of $V$. alginolyticus isolated from diseased silver sea bream Sparus sarba was achieved and the effects of live $V$. alginolyticus and ECP on hepatic heat shock protein (hsp) expression was compared. The ECP fraction was found to contain several hydrolytic enzymes including both haemolytic and proteolytic activities. Intramuscular administration of ECP to sea bream resulted in vibriosis with similar pathological signs as those observed with live $V$. alginolyticus administration. Using quantitative immunoassays we assessed the levels of the major hsp families, hsp90, hsp70 and hsp60, in hepatic tissue of diseased sea bream between 12 and $48 \mathrm{~h}$ post-infection. Throughout the infective period, live $V$. alginolyticus did not alter hsp90 whereas ECP significantly reduced hepatic hsp90 during the late stages of acute infection. The levels of hsp70 were found to be rapidly and drastically increased with both live $V$. alginolyticus and ECP. The transcript levels of both gene members of the hsp70 family ( $h s c 70$ and $h s p 70$ ) were significantly increased with both live $V$. alginolyticus and ECP. The levels of hsp60 remained unchanged with both live $V$. alginolyticus and ECP. The data presented in this study is the first report describing an effect of both live $V$. alginolytus and ECP on hsp expression in diseased fish.
\end{abstract}

KEY WORDS: Fish $\cdot$ Disease $\cdot$ Vibrio $\cdot$ Heat shock protein $\cdot$ hsp90 $\cdot$ hsp70 $\cdot$ hsp60

Resale or republication not permitted without written consent of the publisher

\section{INTRODUCTION}

Under certain culture conditions, fish can be exposed to both abiotic and biotic stress including adverse water quality, hypoxia and infectious diseases. A significant group of bacterial pathogens which are predominant in marine fish belong to the genus Vibrio and members of this genus are Gram-negative and are found ubiquitously in both marine and estuarine environments. Certain strains of Vibrio are pathogenic for different species of aquatic animals causing the diseased condition termed vibriosis. Classic signs of vibriosis include general bacterial septicaemia, haemorrhaging and skin lesions (Egidus 1987). Although the onset of vibriosis is generally associated with physical damage to the fish outer integument or poor culture conditions (Colorni et al. 1981) it is possible that certain highly infectious strains such as those of $V$. anguillarum and $V$. salmonicida can cause vibriosis without a pre-disposing factor (Hjeltnes \& Roberts 1993). Pathogenic Vibrio species possess an array of key components which allow for host invasion and proliferation, and a key strategy for Vibrio virulence is related to the capability to sequester iron from host tissues using a complex of siderophores and iron transporting proteins coded for by either plasmid or chromosomal located genes (Crosa 1980, 1984, Actis et al. 1985, Conchas et al. 1991). Also, enzymatic virulence factors associated with the extracellular products (ECPs) have been demonstrated to be toxic to fish (Biosca \& Amaro 1996, Lee et al. 1997, Liu et al. 1997, Perez et al. 1998) and of the many components found in $\mathrm{ECP}$, protease and haemolysins are known to play a major role in host tissue liquefaction and erythrocyte destruction respectively (Kodama et al. 1984, Kreger et al. 1987). 
When normal cellular processes are adversely affected the synthesis of a group of proteins belonging to the heat shock protein (hsp) families (hsp90, hsp70 and hsp60) are rapidly increased. Members of these different hsp families play different roles in the cell; for example, the hsp90 family is involved in steroid receptor formation and protein folding (Smith \& Toft 1993, Pratt 1997), the hsp70 family is necessary for protein synthesis, translocation and protein folding (Gething \& Sambrook 1992), and mitochon-drial bound hsp60 is defined as being involved in protein stability and folding (Cheng et al. 1989, Ostermann et al. 1989, Martin et al. 1992). Indeed all of these groups of hsps have been demonstrated to be upregulated in fish during abiotic stress (Iwama et al. 1998). Evidence from mammalian studies has suggested that hsps are important during disease as they may play critical roles in immune function and protection (Jacquier-Sarlin et al. 1994), antigen presentation (DeNagel \& Pierce 1993) and non-specific immune responses (Guzik et al. 1999). Although strong evidence exists for an important role of hsps in disease responses for mammals, much less is known about pathogenic stress and its effect on hsp90, 70 and 60 expression in fish. A better understanding on how all of these cytoprotective proteins are modulated during fish disease would aid our understanding of the host response. In coho salmon both hepatic and renal hsp70 were increased during infection with Renibacterium salmonarium (Forsyth et al. 1997) and similarly Vibrio anguillarum infection resulted in elevated hsp70 in liver and head kidney in juvenile rainbow trout (Ackerman \& Iwama 2001). A chinook salmon embryo cell line (CHSE-214) exposed to heat shock displayed an induction of a $90 \mathrm{kDa}$ protein. This protein was also induced upon exposure of CHSE-214 cell line to an infectious strain of haematopoietic necrosis virus (IHNV) (Lee et al. 1996). Although, at first sight, this protein appeared to be a member of the hsp90 family, further characterization based on molecular mass, antigenic properties, subcellular distribution and subsequent gene isolation proved that this protein was not hsp90 but a putative extracellular solute binding protein (Cho et al. 1997, 2002); thus the expression of hsp90 during fish disease still remains to be established. The present study was performed in order to obtain new information on pathogenesis mechanisms of $V$. alginolyticus particularly in relation to effects on host hsp expression. As pathogenesis mechanisms could differ between infection caused by live bacterium and infection caused by ECP, a clear delineation between these 2 components in terms of effects on host hsp expression was also studied. A better understanding of $V$. alginolyticus pathogenicity as well as the host response to infection will certainly help to design future strategies of disease prevention and protection. Here we report on the partial biochemical characterization of the ECP from a pathogenic $V$. alginolyticus strain isolated from silver sea bream Sparus sarba. We also report on the effects of both live $V$. alginolyticus and ECP administration on the expression of major heat shock protein families hsp90, hsp70 and hsp60 in sea bream hepatic tissues.

\section{MATERIALS AND METHODS}

Experimental fish. Juvenile silver sea bream Sparus sarba weighing approximately 15 to $20 \mathrm{~g}$ were obtained from a local fish farm with no reported history of vibriosis. Fish were allowed to acclimate to laboratory conditions in seawater stock tanks for $2 \mathrm{wk}$ prior to experimentation. Fish were separated into experimental tanks (500 l) equipped with a seawater recirculation and fed on a prepared diet (Woo \& Kelly 1995). The temperature of the experimental tanks was maintained at 20 to $22^{\circ} \mathrm{C}$ throughout the experimental period.

Heat shock regime. For the determination of hsp expression, an acute heat shock procedure was used. Fish were divided into 3 groups $(\mathrm{n}=5)$ and acclimated to opaque laboratory aquaria for $2 \mathrm{~d}$ prior to heat shock experiments. The seawater in the aquaria was changed daily and one group served as a control with water temperature maintained at 20 to $22^{\circ} \mathrm{C}$. The second group of fish were subjected to a temperature increase of approximately $0.12^{\circ} \mathrm{C} \mathrm{min}{ }^{-1}$ using an immersion heater until $32^{\circ} \mathrm{C}$ was attained, and the fish were maintained at this temperature for a further $2 \mathrm{~h}$ after which time they were killed by spinal transection and the liver was removed. A third group of fish was also subjected to the same temperature stress of $32^{\circ} \mathrm{C}$ in the same manner as above and after $2 \mathrm{~h}$ the immersion heater was removed and the fish were allowed to undergo a recovery period of $24 \mathrm{~h}$ at 20 to $22^{\circ} \mathrm{C}$ prior to tissue removal.

Bacteria and ECP preparation and toxicity test. A strain of pathogenic Vibrio alginolyticus previously isolated from diseased sea bream and shown to cause vibriosis (Li et al. 1999, Deane et al. 2001) was cultured for $24 \mathrm{~h}$ on 2216E marine agar (Difco Laboratories) and then resuspended in sterile saline $(0.85 \% \mathrm{w} / \mathrm{v} \mathrm{NaCl})$. Viable counts were determined by spreading serially diluted bacterial suspensions on TCBS selective agar (Oxoid) and incubated at $28^{\circ} \mathrm{C}$ for $48 \mathrm{~h}$. The ECP from $V$. alginolyticus was obtained using the cellophane plate technique (Liu 1957). Sterile cellophane sheets were placed onto the surface of 2216E agar plates and inoculated with $0.2 \mathrm{ml}$ of an overnight culture of $V$. alginolyticus. Plates were incubated at $28^{\circ} \mathrm{C}$ for $24 \mathrm{~h}$ 
and then cellophane disks were washed with $3 \mathrm{ml}$ of cold 0.01M phosphate buffered saline (PBS, $\mathrm{pH} 7.2$ ). The bacteria were pelleted by centrifugation at 12000 $\times g$ for $20 \mathrm{~min}$, the supernatant was collected, filtersterilized through a $0.22 \mu \mathrm{m}$ membrane (Millipore) and the protein content of the preparation was determined (Lowry et al. 1951). Groups of juvenile sea bream were given intramuscular injections of either saline, a predetermined $\mathrm{LD}_{50}$ dose of $V$. alginolyticus $\left(4.85 \times 10^{4} \mathrm{cfu}\right.$ fish $^{-1}$ ) or a pre-determined $\mathrm{LD}_{50}$ dose of ECP (0.92 mg protein $g$ body weight ${ }^{-1}$ ). After injections were completed, fish were divided into separate groups $(\mathrm{n}=5)$ for sacrifice at 12, 24, 36 and $48 \mathrm{~h}$ intervals post-injection. To assess if any changes could have been caused by the handling or injection of fish per se a group of fish $(\mathrm{n}=7)$ which were not subjected to injections (intact control) was also killed. Fish were killed by spinal transection and the liver was removed, quickfrozen in liquid nitrogen and then stored at $-70^{\circ} \mathrm{C}$ until analysis.

Partial biochemical characterization of bacteria and ECP. The enzymatic and haemolytic activities of live Vibrio alginolyticus and the prepared ECP were determined using plate assays as previously described (Sudheesh \& Xu 2001). Agarose plates supplemented with either $1 \% \mathrm{w} / \mathrm{v}$ caseinate, $1 \% \mathrm{w} / \mathrm{v}$ gelatin, $0.2 \%$ w/v starch, $2.5 \%$ v/v egg yolk, $1 \%$ v/v Tween 80 or $0.3 \% \mathrm{w} / \mathrm{v}$ chitin were used for caseinase, gelatinase, amylase, lecithinase, lipase and chitinase determination respectively. Haemolytic activity was determined using blood agar supplemented with either $5 \%$ v/v silver sea bream, black sea bream or rabbit erythrocytes. Activities were determined by spot inoculating ECP $(25 \mu l)$ into small wells cut into agarose plates. The appearance of a clear lytic halo around each well was considered as positive and the ratio of the diameter of the lytic halo to that of the colony well was calculated. Total proteolytic activity of ECP was determined using a multiprotein substrate, azocasein (Sigma) and the inhibitory effects of $10 \mathrm{mM}$ concentrations of phenylmethylsulfonyl fluoride (PMSF), ethylenediaminetetraacetic acid (EDTA), ethylene glycol-bis (2-aminoethyl-ether) $\mathrm{N}, \mathrm{N}_{1} \mathrm{~N}^{\prime}, \mathrm{N}^{\prime}$ tetraacetic acid (EGTA), sodium dodecyl sulfate (SDS), $\mathrm{HgCl}_{2}$ and $\mathrm{KMnO}_{4}$ were determined as previously described (Lee 1995). One unit of proteolytic activity was defined as an increase in absorbance of 0.001 at $440 \mathrm{~nm}$.

Protein extraction and quantification. Liver samples were homogenized in $1 \mathrm{ml}$ of protein extraction buffer (4 M urea, 0.5\% w/v SDS, 2 mM PMSF, 10 mM EDTA) using an Ultra-Turrax T25 rotor stator homogenizer for $30 \mathrm{~s}$, and then incubated at $95^{\circ} \mathrm{C}$ for $10 \mathrm{~min}$. The samples were then sonicated for $10 \mathrm{~min}$, centrifuged at $12000 \times g$ for $10 \mathrm{~min}$ and the supernatant was decanted and measured for total protein content (Lowry et al. 1951). Samples were read at $595 \mathrm{~nm}$ using a spectrophotometer (Milton Roy Spectronic) and protein concentration calculated from a protein standard curve of bovine albumin (Sigma).

Protein gel electrophoresis and immunoblotting. One-dimensional SDS-PAGE was applied to resolve proteins of different molecular size according to the procedure described by Laemmli (1970) using a $4 \%$ (stacking) and $12 \%$ (separating) polyacrylamide gel. The standard proteins used for SDS-PAGE were bovine brain hsp70 and hsp90 and human recombinant hsp60 (Sigma). For electrophoresis, $1.5 \mu \mathrm{g}$ of full range rainbow molecular weight marker (Amersham), $0.1 \mu \mathrm{g}$ of hsp standard protein and a representative liver protein sample $(5 \mu \mathrm{g})$ was electrophoresed for $90 \mathrm{~min}$ at $100 \mathrm{~V}$ followed by transfer to nitrocellulose membrane (Gibco-BRL) for $1 \mathrm{~h}$ at $150 \mathrm{~V}$ using a BioRad mini kit. After protein transfer the membrane was air dried and then blocked by immersing overnight at $4{ }^{\circ} \mathrm{C}$ in PBS containing $3 \% \mathrm{w} / \mathrm{v}$ skimmed milk powder. The membranes were rinsed for $1 \mathrm{~h}$ in PBS containing $0.05 \% \mathrm{v} / \mathrm{v}$ Tween 20 (PBS-T) and then incubated for $1 \mathrm{~h}$ with anti-mouse hsp antiserum (Sigma) diluted in PBS-T. The dilutions of hsp90, 70 and hsp60 antiserum were $1: 500,1: 4000$ and 1:1000 respectively. The membranes were rinsed for a further $1 \mathrm{~h}$ in PBS-T before incubating with antimouse IgG horseradish peroxidase conjugate (Sigma) diluted 1:8000. After a final membrane rinse, the bound hsps were detected using an ECL development system (Amersham) and followed by exposure to Hyperfilm (Amersham).

Hsp analysis using quantitative immuno-dot blot. Quantitative immuno-dot blots were used to assess all samples for hsp90, 70 and 60 amounts as described by Deane et al. (2002). Nitrocellulose membranes were prepared for blotting by immersing in $0.1 \mathrm{M}$ PBS for $10 \mathrm{~min}$ and then fixed into a Bio-Dot microfiltration manifold (Bio-Rad). An aliquot of $5 \mu \mathrm{g}$ total protein from each sample was adjusted to $100 \mu \mathrm{l}$, added to the wells of the manifold and a vacuum was used to draw the samples onto the membrane. For every immunodot blot a series of hsp standards (1 to $100 \mathrm{ng}$ ) were also applied. In order to ensure that all of the protein sample was drawn onto the membrane, each well of the manifold was washed with a further $200 \mu \mathrm{l}$ of $0.1 \mathrm{M}$ PBS. The samples were fixed onto the membranes by air drying overnight and membranes were probed and visualized as previously described. For each sample the optical density $(\mathrm{OD}) \times$ area $\left(\mathrm{mm}^{2}\right)$ was determined using a GS-690 densitometer (Bio-Rad). The hsp content of each larval sample was calculated from the standard curves of hsp90, 70 or 60 .

Reverse transcriptase polymerase chain reaction (RT-PCR) of hepatic hsc70 and hsp70 gene transcripts. Total RNA was extracted from hepatic tissue of exper- 
imental fish using a Qiagen RNeasy mini kit (Qiagen) and treated with DNaseI (Gibco-BRL). For first strand cDNA synthesis, $1 \mu \mathrm{g}$ of total RNA from each sample was added to a reaction mix $(20 \mu \mathrm{l})$, containing $0.5 \mu \mathrm{g}$ oligo DT primer (Pharmacia, LKB), $2 \mu$ dithiothreitol (0.1 M), $1 \mu \mathrm{l}$ dNTP mix (10 mM, Pharmacia, LKB), $4 \mu \mathrm{l}$ reaction buffer and $1 \mu \mathrm{l}$ of Superscript II reverse transcriptase (200 $\mathrm{U} \mathrm{\mu l}^{-1}$, Gibco-BRL). First-strand cDNA synthesis was allowed to proceed at $42^{\circ} \mathrm{C}$ for $1 \mathrm{~h}$ after which time the reaction was incubated at $70^{\circ} \mathrm{C}$ for $15 \mathrm{~min}$ and then stored at $4^{\circ} \mathrm{C}$. PCR amplification of first-strand cDNA was performed with a series of oligonucleotide primers designed from previously cloned hsc70 (cognate) and hsp70 (inducible) genes of silver sea bream (GenBank accession numbers AY436786 and AY436787 respectively). As a normalization control for each RT-PCR, primers specific for a 540 base pair fragment of 18S rRNA were designed according to previously published sequence (Harasewych et al. 1997). All primers were synthesized by Genset (Singapore) and had the following sequences: Hsc70:

5'-ATCAGTGATGACGACAA-3' (sense)

5'-TGACCCCCCCCCAGGGGC-3' (antisense) Hsp70:

5'-ATCAGTGAGGAGGACAAA-3' (sense)

5'-CTGGGAGCCGCTTCCTGC-3' (antisense) 18s rRNA:

5'-GCCAAGTAGCATATGCTTGTCTC-3' (sense)

5'-AGACTTGCCTCCAATGGATCC-3' (antisense)

For each pair of specific primers, a PCR reaction $(50 \mu \mathrm{l})$ containing $5 \mu \mathrm{l}$ of first-strand cDNA, $0.2 \mu \mathrm{l} \mathrm{Taq}$ DNA polymerase $\left(5 \mathrm{U} \mathrm{\mu l}^{-1}\right.$, Promega $), 5 \mu \mathrm{l} \mathrm{MgCl}_{2}$ $(25 \mathrm{mM}), 5 \mu \mathrm{l}$ reaction buffer, $0.5 \mu \mathrm{dNTP}$ mix $(10 \mathrm{mM})$ and $1 \mu \mathrm{l}$ of each primer $(50 \mathrm{pM})$ was prepared. PCR amplification was performed using a PTC-100 thermal cycler (MJ Research) with cycle parameters of $94^{\circ} \mathrm{C}$ for $1 \mathrm{~min}, 55^{\circ} \mathrm{C}$ for $1 \mathrm{~min}, 72^{\circ} \mathrm{C}$ for $1 \mathrm{~min}$ and a final extension of $72^{\circ} \mathrm{C}$ for $4 \mathrm{~min}$. Amplification of $h s c 70$ and $h s p 70$ transcripts were performed using 23 and 31 cycles of amplification respectively, since preliminary experiments demonstrated these parameters would allow for transcript amplification within the linear phase of the PCR. All PCR products were run on a $2 \% \mathrm{w} / \mathrm{v}$ agarose gels (Bio-Rad) and gels were stained with ethidium bromide to visualize bands. Negative controls were performed with RNA samples subjected to the above conditions, without the addition of reverse transcriptase; no PCR products were detected for negative controls indicating that the amplified gene fragments were from first-strand CDNA template. A single PCR product of 237 and 204 base pairs was obtained for hsC70 and hsp70 amplification respectively and in order to confirm the identity of these we subcloned fragments into pCRscript plasmid vector (Stratagene) and cycle sequenced using an ABI PRISM dye terminator kit with reaction products run on an ABI 310 Genetic Analyzer (Perkin Elmer). All PCR samples were stored at $4^{\circ} \mathrm{C}$.

Semi-quantification of hsc70 and hsp 70 transcripts. In order to analyze all samples together DNA dot blots were prepared using a Bio-Dot microfiltration manifold (Bio-Rad). PCR amplification products $(10 \mu \mathrm{l})$ from all samples were diluted 2-, 4- and 8-fold in order to confirm a linearity of detection during subsequent scanning procedures and blotted according to instructions supplied with Hybond-N+ membrane (Amersham). Membranes were then rinsed briefly in $20 \times \mathrm{SSC}$ $(17.5 \% \mathrm{w} / \mathrm{v} \mathrm{NaCl}, 8.8 \% \mathrm{w} / \mathrm{v}$ trisodium citrate), and the DNA fixed to the membrane by UV cross-linking. For probing, purified cDNA fragments of each gene of interest were radiolabeled using a Rediprime random labelling kit (Amersham) and used for membrane hybridization in Rapid-Hyb buffer (Amersham) at $55^{\circ} \mathrm{C}$ for $16 \mathrm{~h}$. After hybridization, membranes were washed twice with a $2 \times \mathrm{SSC} / 0.1 \% \mathrm{SDS}$ solution for $30 \mathrm{~min}$ followed by a final wash in $0.1 \times \mathrm{SSC} / 0.1 \% \mathrm{SDS}$ at $65^{\circ} \mathrm{C}$ for $15 \mathrm{~min}$ and then exposed to a storage phosphor screen (Molecular Dynamics) for $3 \mathrm{~h}$ at room temperature. The plates were scanned using the Storm PhosphorImaging system with ImageQuant software (Molecular Dynamics) for quantification of amplified fragments. The abundance of each specific gene fragment was normalized to the corresponding $18 \mathrm{~S}$ cDNA abundance from the same sample.

Statistical analysis. Data from quantitative hsp immuno blots and DNA dot blots were subjected to a 1-way ANOVA. In order to delineate significance between groups a Student-Newman-Keuls test (Jandel Scientific) was used. Significance was accepted if $p<$ 0.05 and all data are expressed as mean \pm SEM.

\section{RESULTS}

\section{Vibrio alginolyticus ECP characterization}

The ECP isolated from a pathogenic strain of Vibrio alginolyticus was assessed for a number of enzymes using plate assays. We detected high amylase and caseinase activities, and moderate chitinase, gelatinase, lecithinase and lipase activities. Haemolytic activity appeared to be specific for fish erythrocytes as no lytic zones were present in agar plates supplemented with rabbit erythrocytes (Table 1). Proteolytic activity was found to be completely inhibited by $\mathrm{KMnO}_{4}$ and partially by PMSF, EDTA and EGTA and $\mathrm{HgCl}_{2}$. SDS seemed to have little effect on proteolytic activity (Table 2). 
Table 1. Enzymatic characterization of the isolated extracellular product (ECP) of pathogenic Vibrio alginolyticus. The activity tested and the respective substrate used for plate assays are indicated. The ratio of hydrolytic zone to well diameter was calculated, $(++)=$ a ratio between 2 and $5,(+)=$ a ratio between 1 and 2 and $(-)=$ no lytic zone observed

\begin{tabular}{|llc|}
\hline $\begin{array}{l}\text { Activity } \\
\text { tested }\end{array}$ & $\begin{array}{l}\text { Substrate } \\
\text { used }\end{array}$ & $\begin{array}{c}\text { Lytic zone } \\
\text { size }\end{array}$ \\
\hline Caseinase & Caseinate & ++ \\
Gelatinase & Gelatin & + \\
Amylase & Starch & ++ \\
Lecithinase & Egg yolk & + \\
Lipase & Tween 80 & + \\
Chitinase & Chitin & + \\
Haemolysin & Silver sea bream erythrocytes & + \\
Haemolysin & Black sea bream erythrocytes & + \\
Haemolysin & Rabbit erythrocytes & - \\
\hline
\end{tabular}

\section{Temperature stress}

Immunoblots were used to determine the presence of hsp families in sea bream hepatic tissue and a single band for each hsp type was observed (Fig. 1). The effect of an acute heat shock on hsp expression was studied using groups of fish subjected to a $+12^{\circ} \mathrm{C}$ increase in water temperature for $2 \mathrm{~h}$ (Fig. 2). Hepatic hsp90, 70 and 60 levels were increased significantly ( $p<0.05$ ) by 1.5-, 2.4 - and 1.7 -fold respectively in comparison with control groups. Fish that were subjected to a $24 \mathrm{~h}$ recovery period following heat shock did not display any significant differences $(\mathrm{p}<0.05)$ in hsp90, 70 or 60 levels when compared to control groups.

\section{Effects of live Vibrio alginolyticus and ECP administration on hepatic hsp expression}

Prior to administration of bacteria or ECP a group of fish were sacrificed and assayed for hsp levels, calculated as $\mu \mathrm{g} \mathrm{mg}^{-1}$ total protein. Hepatic hsp90, 70 and 60 levels were $14.9 \pm 1.8,2.8 \pm 0.4$ and $14.1 \pm 1.7 \mu \mathrm{g}$ $\mathrm{mg}^{-1}$ total protein respectively and these values served as intact controls. Fish injected with live bacteria exhibited pathological signs of disease such as abdominal swelling, haemorrhaging and ulceration around the site of injection. Similar pathological signs of diseases were observed with fish injected with ECP and no pathological signs of disease were observed in fish injected with a pre-heated $\left(70^{\circ} \mathrm{C}\right) \mathrm{ECP}$ preparation.

The expression of hsp families during live Vibrio alginolyticus infection and ECP administration was assessed. Hepatic hsp90 remained unchanged with live $V$. alginolyticus administration in comparison to controls at all time points assessed. When ECP was used it was found that hsp90 amounts were significantly decreased by 29
Table 2. Effect of various inhibitors on proteolytic activity of Vibrio alginolyticus extracellular product (ECP). Isopropanol was used to dissolve PMSF and distilled water was used to dissolve all other inhibitors. The concentration of each inhibitor used was $10 \mathrm{mM}$ and relative activity is expressed as a percentage of that obtained with respective control

\begin{tabular}{lr}
\hline Inhibitor & $\%$ Relative \\
\hline Control (distilled water) & 100 \\
Control (isopropanol) & 100 \\
SDS & 96 \\
$\mathrm{HgCl}_{2}$ & 64 \\
$\mathrm{EGTA}$ & 6 \\
EDTA & 5 \\
$\mathrm{PMSF}_{\mathrm{KMnO}_{4}}$ & 5 \\
\end{tabular}
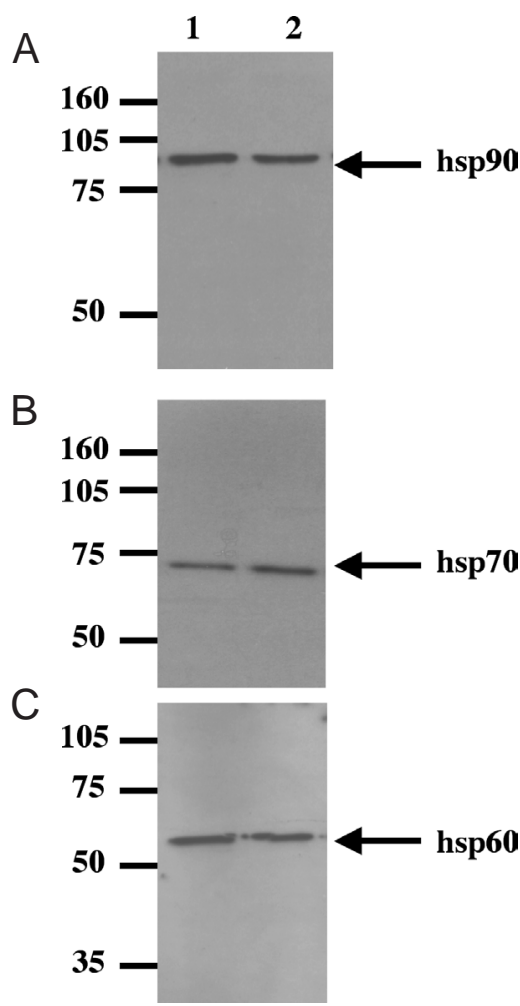

Fig. 1. Immunoblot detection of silver sea bream hepatic (A) hsp90, (B) hsp70 and (C) hsp60. For each immunoblot, standard and hepatic hsp are indicated in Lanes 1 and 2, respectively. The position of protein molecular size markers in $\mathrm{kDa}$ is indicated to the left of each immunoblot

and $59 \%$ at 36 and $48 \mathrm{~h}$ post-infection respectively, in comparison to control groups (Fig. 3). Hepatic hsp70 was significantly increased by $3.1-, 4.0$ - and 2.9-fold at 24, 36 and $48 \mathrm{~h}$ post-infection respectively, with live $V$. alginolyticus administration, and also increased by 2.8-, 2.0, 3.0 - and 3.4-fold at 12, 24, 36 and $48 \mathrm{~h}$ post-infection respectively following ECP administration (Fig. 4). Throughout the time course of this study it was found 


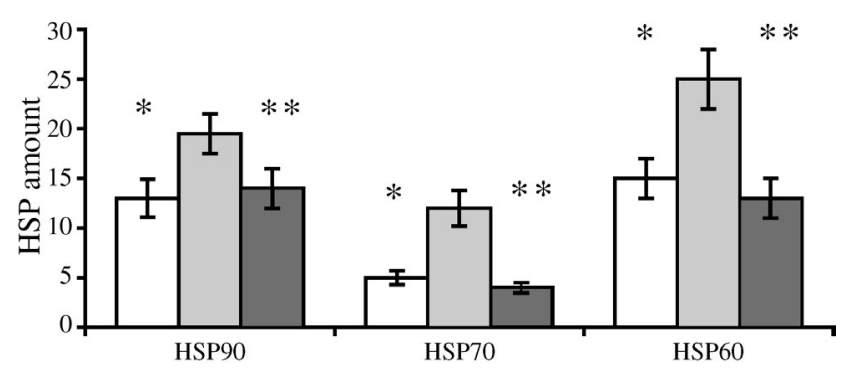

Fig. 2. Effect of heat shock on silver sea bream hepatic hsp90, 70 and 60 . The hsp values for control $\left(20^{\circ} \mathrm{C}\right.$, white columns), heat shock $\left(32^{\circ} \mathrm{C}\right.$ for $2 \mathrm{~h}$, light grey columns) and heat shock followed by $24 \mathrm{~h}$ recovery period (dark grey columns) are indicated. Hsp values are calculated as $\mu \mathrm{g} \mathrm{mg}^{-1}$ total protein and data are expressed as mean \pm SEM $(n=5)$. *Significant $(\mathrm{p}<0.05)$ differences between control and heat shock groups; **significant $(\mathrm{p}<0.05)$ differences between heat shock and heat shock + recovery groups

that hepatic hsp60 levels were not significantly changed with administration of either live $V$. alginolyticus or ECP in comparison to saline controls (Fig. 5).

\section{RT-PCR analysis of hsc70 and hsp 70 transcripts}

Using primers specific for either hsc70 or hsp70 in RT-PCR analysis it was possible to detect both transcripts; radioisotope probing of immobilized DNA followed by subsequent high stringency washing was used for semi-quantification of these transcripts. Using this approach it was determined that the basal level of hsC70 transcript was approximately 12-fold higher than hsp70 transcript in unstressed fish (Figs. 6 \& 7). Analysis of hsc70 transcript showed that treatment with live Vibrio alginolyticus caused an increase of 1.6-, 1.7- and 1.9-fold at 24, 36 and 48 h post-infection respectively in comparison to control groups; treatment with ECP caused an increase of 1.9-, 2.4- and 2.5 -fold at 24, 36 and $48 \mathrm{~h}$ post-infection respectively in comparison to control groups (Fig. 6). Analysis of hsp70 transcript showed that treatment with live $V$. alginolyticus caused a greater increase of 3.4-, 4.0and 3.2-fold at 24, 36 and $48 \mathrm{~h}$ post- infection respectively in comparison to control groups; treatment with ECP also caused an increase of 2.2-, 3.7-, 3.6- and 3.9-fold at 12, 24, 36 and 48 h post-infection respectively in comparison to control groups (Fig. 7).

\section{DISCUSSION}

Many virulent factors, including bacterial surface proteins and iron uptake systems, have been attributed to pathogenicity in Vibrio spp. infections (Toranzo \&
Barja 1993). In addition, the ECP fractions from pathogenic Vibrio appear to play a major role during disease and the enzymatic components of this fraction have been implicated as important factors necessary for invasion, survival and proliferation in host fish (Balebona et al. 1998, Wang et al. 1998, Wang \& Leung 2000). Although ECP is an important factor in pathogenesis, a positive correlation between the pathogenicity of a particular strain of Vibrio and the virulence of the ECP from the same strain cannot be assumed as cytotoxicity of ECP prepared from nonpathogenic Vibrio strains can also occur (Toranzo et al. 1983). Since ECP is a complex of enzymatic and nonenzymatic components, the profiles of which are unique in different species of Vibrio, a complete biochemical profile of this isolated fraction is difficult. However, a partial biochemical characterization of the ECP fraction from a pathogenic strain of $V$. alginolyticus showed the presence of certain key enzymes (caseinase, gelatinase, amylase, lecithinase, lipase, chitinase and protease). The detection of these enzymes was in agreement with the ECP enzymatic profile previously reported for $V$. parahaemolyticus although the ECP of $V$. parahaemolyticus exhibited greater activities for these enzymes using identical plate assays (Sudeesh \& Xu 2001). Of particular interest was the occurrence of protease activity in the iso-
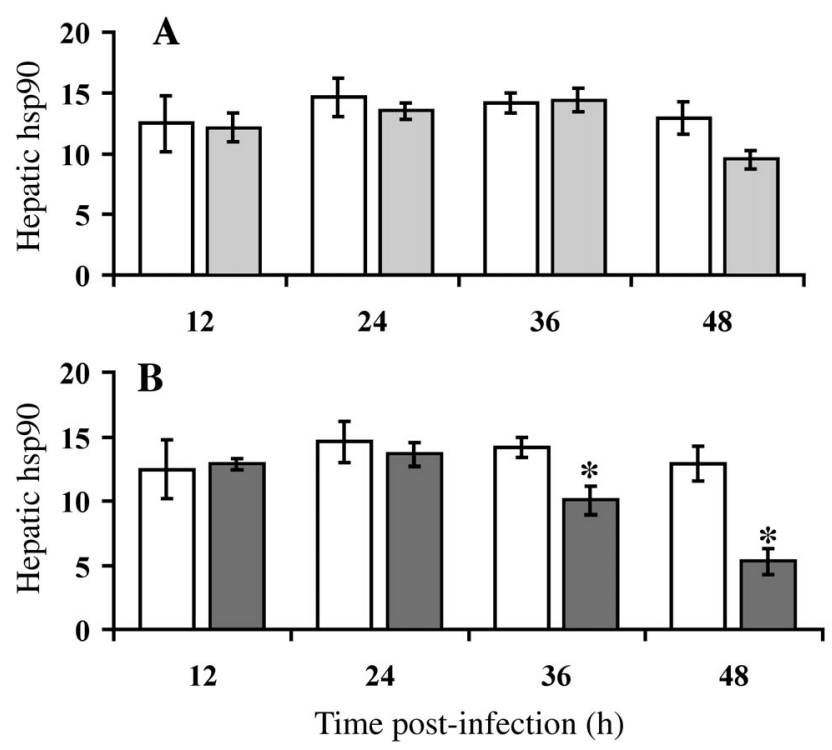

Fig. 3. Hepatic hsp90 expression during acute infection with (A) live Vibrio alginolyticus or (B) ECP. Hepatic hsp90 values are calculated as $\mu \mathrm{g} \mathrm{mg}^{-1}$ total protein and data are expressed as mean \pm SEM $(n=5)$. White columns indicate saline control, light grey columns indicate $V$. alginolyticus treated groups and dark grey columns indicate ECP treated groups. An asterisk above a column indicates a significant difference $(\mathrm{p}<$ 0.05 ) from saline control at the same time point. The amount of hepatic hsp90 in intact control fish was calculated as $14.9 \pm$ $1.8 \mu \mathrm{g} \mathrm{mg}^{-1}$ total protein $(\mathrm{n}=7)$ 

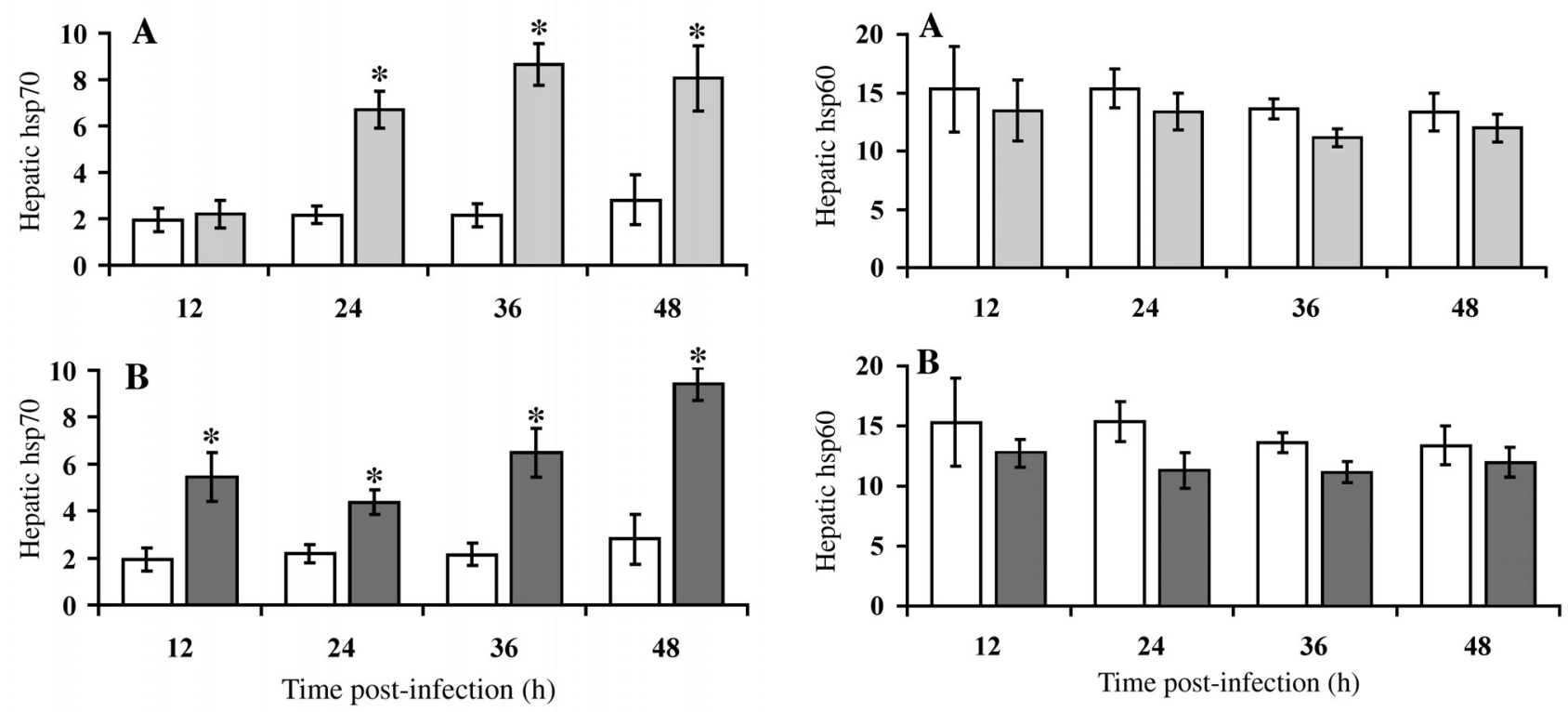

Fig. 4. Hepatic hsp70 expression during acute infection with (A) live Vibrio alginolyticus or (B) ECP. Hepatic hsp70 values are calculated as $\mu \mathrm{g} \mathrm{mg}^{-1}$ total protein and data are expressed as mean \pm SEM $(n=5)$. White columns indicate saline control, light grey columns indicate $V$. alginolyticus treated groups and dark grey columns indicate ECP treated groups. An asterisk above a column indicates a significant difference $(\mathrm{p}<$ 0.05 ) from saline control at the same time point. The amount of hepatic hsp70 in intact control fish was calculated as $2.8 \pm$ $0.4 \mu \mathrm{g} \mathrm{mg}^{-1}$ total protein $(\mathrm{n}=7)$

lated ECP of $V$. alginolyticus as this appears to be one of the most important factors for virulence (Inamura et al. 1984, Kanemori et al. 1987) and it has been demonstrated that purified proteases from Vibrio are toxic to fish (Lee 1995) and shellfish (Sudheesh \& Xu 2001). The protease activity detected in the isolated ECP in this study was completely inhibited by $\mathrm{KMnO}_{4}$, and partially by $\mathrm{HgCl}_{2}$, PMSF, EDTA, EGTA indicating the existence and importance of sulphydryl groups and metalloprotease components. Using blood agar plates, lytic zones were detected with sea bream erythrocytes but not rabbit erythrocytes indicating the presence of haemolytic activity specific for fish blood cells. Such an activity for infective $V$. alginolyticus would be critical as the first step of essential iron release from erythrocytes. The effects of ECP administration was tested by intramuscular administration of an $\mathrm{LD}_{50}$ dose to sea bream and it was clear that ECP could cause disease with similar pathological signs as those associated with a live $V$. alginolyticus infection. It was also observed that there was a considerable degree of ulceration and degradation of tissue surrounding the site of ECP injection in sea bream. This ulceration was probably caused by the concerted action of enzymes associated with ECP. No disease or disease signs were detected in

Fig. 5. Hepatic hsp60 expression after injection with (A) live Vibrio alginolyticus or (B) ECP. Hepatic hsp60 values are calculated as $\mu \mathrm{g} \mathrm{mg}^{-1}$ total protein and data are expressed as mean \pm SEM $(n=5)$. White columns indicate saline control, light grey columns indicate $V$. alginolyticus treated groups and dark grey columns indicate ECP treated groups. No significant differences between treatments and saline control were found. The amount of hepatic hsp60 in intact control fish was calculated as $14.1 \pm 1.7 \mu \mathrm{g} \mathrm{mg}^{-1}$ total protein $(\mathrm{n}=7)$

preliminary experiments with pre-heated ECP (results not shown) therefore adding further support to the importance of enzymatic activities for virulence.

In this study, immunoblotting was used to determine that levels of hepatic hsp90, 70 and 60 increased upon acute heat shock and returned to pre-stress levels following a recovery period confirming a role of these hsps as stress associated proteins. Presently there is a paucity of data concerning the effect of pathogenic stress on hsps in fish and in this study the concerted expression profiles of the key hsp families, hsp90, hsp70 and hsp60, in fish infected with a pathogenic strain of $V$. alginolyticus is reported. Also, a comparison of effects of live $V$. alginolyticus and its ECP was studied.

Of all the hsps, the hsp70 family has been most widely studied as a biomarker of stress because of its rapid and significant increase during cellular disruption (Ryan \& Hightower 1996). One of the major inducing factors for hsp70 upregulation in the cell is the occurrence of damaged cellular proteins (Ananthan et al. 1986) and the key role of hsp70 is to repair such proteins (Gething \& Sambrook 1992). During stressful situations such as host tissue undergoing destruction from infective agents, we would expect damaged cellular proteins and a subsequent hsp70 increase to 
A

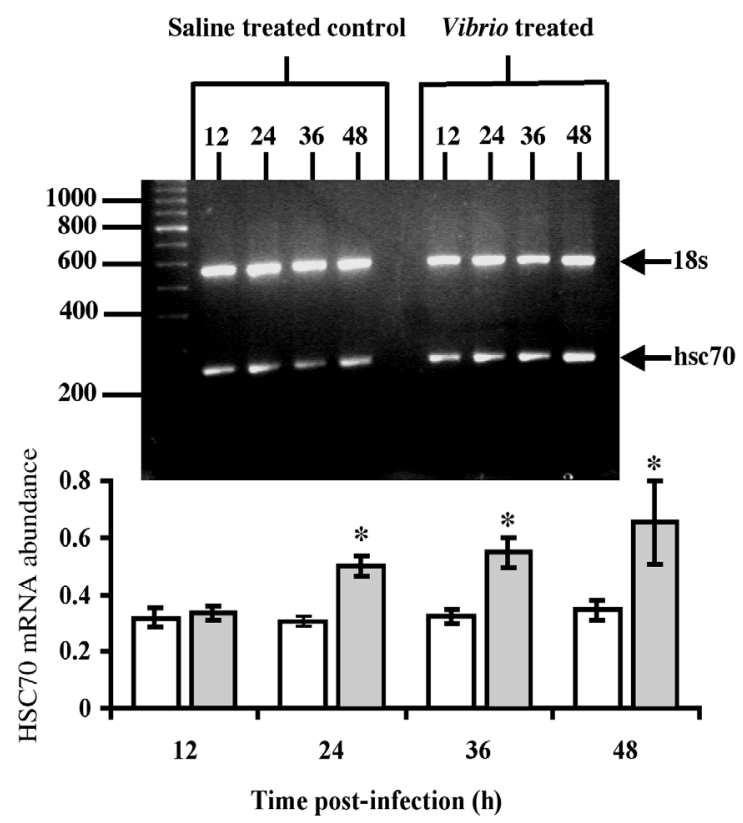

B

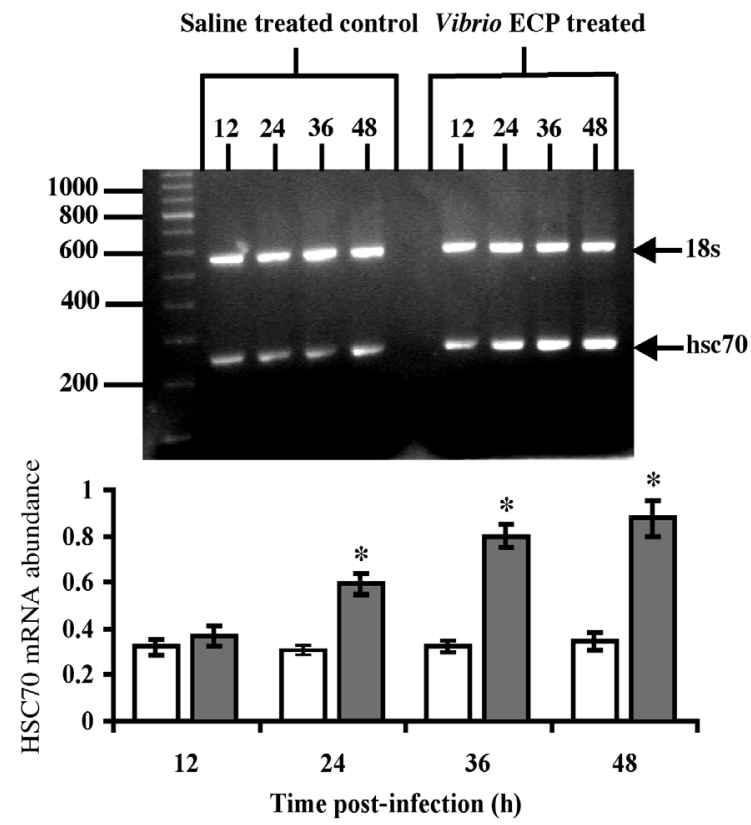

Fig. 6. Hepatic hsc70 transcript expression after injection with (A) live Vibrio alginolyticus or (B) ECP. A representative agarose gel of RT-PCR products taken from different treatment groups is shown above a bar chart and each lane is labelled according to time post-infection (h). Molecular size markers are shown on the left (in base pairs) and $18 \mathrm{~s}$ and hsc70 transcripts are indicated. For bar charts, the transcript levels are expressed as normalized values (arbitrary units) and data are expressed as mean $\pm \operatorname{SEM}(n=5)$. White columns indicate saline control, light grey columns indicate $V$. alginolyticus treated groups and dark grey columns indicate ECP treated groups. An asterisk above a column indicates a significant difference $(p<0.05)$ from saline control at the same time point. The amount of hepatic hsc70 in intact control fish was calculated as $0.32 \pm 0.34(\mathrm{n}=7)$
A

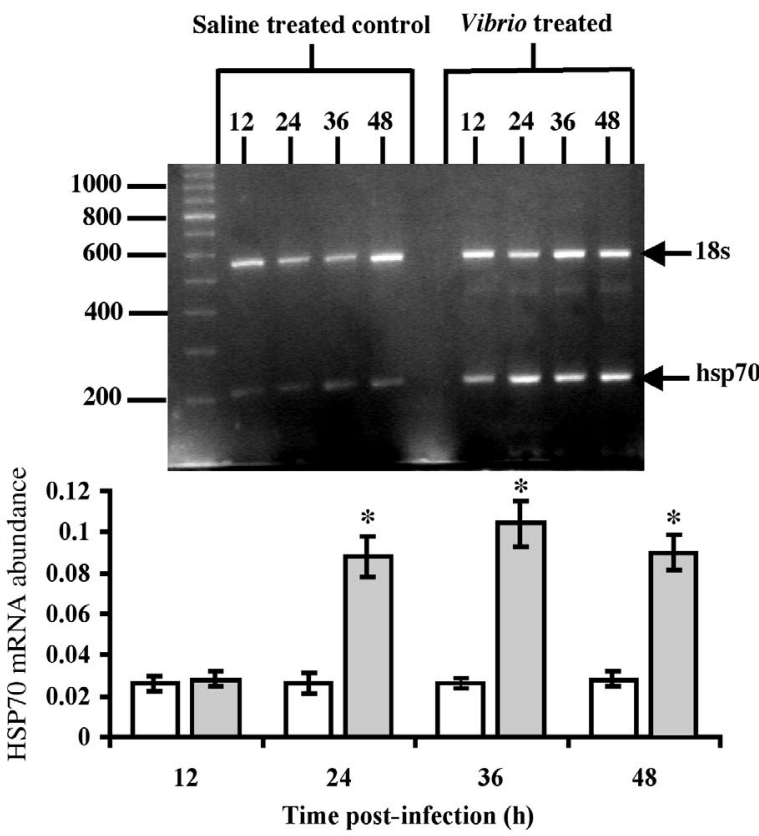

B

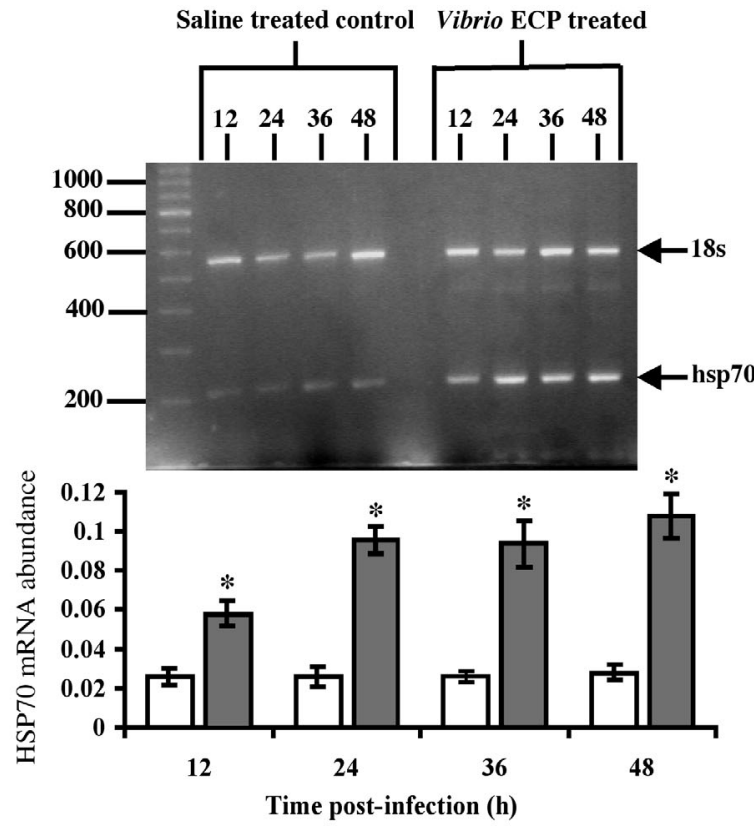

Fig. 7. Hepatic hsp70 transcript expression after injection with (A) live Vibrio alginolyticus or (B) ECP. A representative agarose gel of RT-PCR products from different treatment groups is shown above a bar chart and each lane is labelled according to time post-infection (h). Molecular size markers are shown on the left (in base pairs) and positions of $18 \mathrm{~s}$ and hsp70 transcripts are indicated. For bar charts the transcript levels are expressed as normalized values (arbitrary units) and data are expressed as mean $\pm \operatorname{SEM}(\mathrm{n}=5)$. White columns indicate saline control, light grey columns indicate $V$. alginolyticus treated groups and dark grey columns indicate ECP treated groups. An asterisk above a column indicates a significant difference $(p<0.05)$ from saline control at the same time point. The amount of hepatic hsp70 in intact control fish was calculated as $0.025 \pm 0.005(n=7)$ 
occur. In this study data from immunoanalysis showed a significant increase in liver hsp70 at $24 \mathrm{~h}$ post-infection and reached peak levels at $36 \mathrm{~h}$. The elevation of hsp70 reported in this study is in general agreement with other studies which have also reported increased hsp70 during fish disease (Forsyth et al. 1997, Ackerman \& Iwama 2001). The levels of hsp70 progressively increased in liver and kidney of coho salmon infected with Renibacterium salmonarium (Forsyth et al. 1997) and an acute Vibrio anguillarum infection caused an increase in hsp70 in liver and head kidney in juvenile rainbow trout (Ackerman \& Iwama 2001). The detected maximal peak of hsp70 in rainbow trout liver occurred approximately $1 \mathrm{~d}$ before peak kidney hsp70, which is suggestive of a tissue type specific response in the dynamics of hsp70 expression. As all of these aforementioned studies have used live bacteria to artificially infect experimental fish, it remains to be established as to whether any observed changes in hsp70 expression can also be mediated via administration of ECP from a pathogenic bacterial strain. To obtain some answers to this, $V$. alginolyticus ECP was administered to sea bream and it was found that a significant increase in hsp70 occurred $12 \mathrm{~h}$ earlier than that seen with live $V$. alginolyticus. The hsp70 family consists of 2 separate and distinct proteins, a cognate type (hsc70) and an inducible type (hsp70). Generally, hsc70 occurs at constitutively expressed levels in unstressed cells whereas hsp70 occurs at very low (sometimes undetectable levels) in unstressed cells but is greatly induced upon exposure to stress. When an antibody capable of detecting both members of the hsp70 family was used, then a clear delineation between separate profiles would not be possible using immunoanalysis alone. To address this issue we used RT-PCR coupled with stringent radioisotope probing to measure separate mRNA transcripts. Using this approach it was found that hsc70 transcript was expressed constitutively with levels 12-fold higher than hsp70 in control fish. Upon exposure to live $V$. alginolyticus it was found that $h s p 70$ was induced to a greater extent (3.4to 4 -fold) than hsc70 (1.6- to 1.9-fold) when compared to control groups. A similar profile was found in ECP administered fish (1.9- to 2.5-fold for hsc70 and 2.2- to 3.9-fold for $h s p 70$ ) and as with immunoanalysis it was observed that $h s p 70$ was induced earlier with ECP treatment. Although both hsc70 and hsp70 perform key roles in the cell as protein chaperones, the major role of $h s c 70$ is generally associated with the protein translocation pathway particularly during clathrin uncoating (Ungewickell 1985, Green \& Eisenberg 1990) whereas the role of inducible $h s p 70$ is associated with cytoprotection via damaged protein repair (Ananthan et al. 1986, Gething \& Sambrook 1992). The induction of $h s c 70$ and hsp70 detected in this study suggests that the key processes of protein translocation and cytoprotection are modulated during disease. The increase of liver hsp70, observed with both Vibrio and $\mathrm{ECP}$, could have occurred via a number of different routes such as: (1) cellular protein damage caused via a direct destruction of host tissue with Vibrio or ECP could have induced $h s p 70$ as damaged proteins are known to serve as triggers for hsp70 transcription (Ananthan et al. 1986); (2) the hypoxaemia associated with erythrocyte destruction could also have induced hsp70 as hypoxic stress has been shown to upregulate hsp70 (Mestril et al. 1994, Kobayashi \& Welsh 1995); and (3) disturbances within the ionic milieu during infection could also cause hsp70 induction as persistent ionic disruption can have deleterious effects on normal cellular processes (Yancey et al. 1982, Burg et al. 1997).

Presently the expression of hsp90 and hsp60 has not been reported in diseased fish although both of these hsp families are induced during abiotic stress of sea bream (Deane et al. 2002). In this study it was found that both hsp90 and hsp60 remained unchanged throughout a live Vibrio infection. However, ECP administration caused a significant decrease in hsp90 after $36 \mathrm{~h}$ post-infection whereas hsp60 remained unaltered. It would appear from the data obtained in this study that certain soluble components found within $V$. alginolyticus ECP can modulate hsp90 in a different manner from that observed with a live Vibrio infection. It has been reported that hsp90 levels were significantly decreased in spleen and liver of Trichinella spiralis-infected rats in comparison to uninfected controls (Martinez et al. 1999a,b). The physiological function of decreased hepatic hsp90 in rats is presently unknown but it was suggested that hsp90 downregulation may be important in parasite establishment or an important factor during the parasite infection cycle (Martinez et al. 1999a,b). In the cell, hsp90 is a critical component for steroid receptor formation (Bresnick et al. 1989, Smith \& Toft 1993, Bamberger et al. 1997, Pratt 1997) and it has been demonstrated that any loss of hsp90 would interfere with steroid receptor function (Picard et al. 1990). The decreased levels of hepatic hsp90 caused by $V$. alginolyticus ECP administration detected in this study would also disrupt steroid receptor function in the liver. Presently it is not possible to draw any firm conclusions as to whether the factors in ECP which are responsible for downregulating hsp90 would be produced by live bacteria in vivo. It may be the case that high levels of such components are necessary for causing decreased hsp90 and as such, modulatory effects may only occur when components are administered in a more concentrated form such as ECP. The observed biological effects of ECP on hsp90 expression may in its simplest case occur by directly 
interfering with liver function or via a more complex route involving elements of the cell signalling pathways. The lack of hsp60 response found in this study may be a consequence of non-inducing signals within mitochondria where hsp60 is located playing an important role in protein folding (Ostermann et al. 1989, Martin et al. 1992). The acute nature of artificial Vibrio infection may not have allowed for a significant hsp60 response although hsp60 can be modulated over chronic periods of stress (Deane et al. 2002).

In summary, we have partially characterized the biochemical properties of the ECP from a pathogenic strain of Vibrio alginolyticus and it does appear that enzymatic components of this fraction play a key role in Vibrio pathogenesis. Importantly, the expression profiles of host hsp90, hsp70 and hsp60 families upon exposure to both live Vibrio and its ECP was described. It is clear that increased hsp70 expression can be mediated by both factors and the rapid and drastic increases in hsp70 during infection add support to its role as a cytoprotective protein. The expression of hsp90 was found to be downregulated by ECP but not live Vibrio, and the factors responsible for such a specific effect await further study. Although it can be concluded that $V$. alginolyticus ECP preparation does have a modulatory effect on certain hsp families, the specific factors responsible for this modulatory effect remain to be established. Since ECP is likely to be composed primarily of a mixture of enzymes with a moderate amount of endotoxin components such as cell wallbound lipopolysaccharide (LPS), a clearer delineation between effects caused by purified ECP and LPS factors awaits further study. Such comparisons between live bacteria, purified ECP factors and LPS would certainly be important in understanding the pathogenic mechanisms of $V$. alginolyticus.

Acknowledgements. This research was supported by Earmarked Grants for Research CUHK4135/98M, CUHK4168/ 99M and CUHK4264/02M (Research Grants Council, Hong Kong) awarded to N.Y.S.W.

\section{LITERATURE CITED}

Ackerman PA, Iwama GK (2001) Physiological and cellular stress responses of juvenile rainbow trout to vibriosis. J Aquat Anim Health 13:173-180

Actis LA, Potter SA, Crosa JH (1985) Iron regulated outer membrane protein OM2 of Vibrio anguillarum is encoded by virulence plasmid JM1. J Bacteriol 161:736-742

Ananthan J, Goldberg AL, Voellmy R (1986) Abnormal proteins serve as eukaryotic stress signals and trigger the activation of heat shock genes. Science 232:522-524

Balebona MC, Andreu MJ, Bordas MA, Zorilla I, Morinigo MA, Borrego J (1998) Pathogenicity of Vibrio alginolyticus for cultured gilthead sea bream (Sparus aurata L.). Appl Environ Microbiol 64:4269-4275

Bamberger CM, Wald M, Bamberger AM, Schulte HM (1997)
Inhibition of mineralocorticoid and glucocorticoid receptor function by the heat shock protein 90 binding agent geldanamycin. Mol Cell Endocrinol 131:233-240

Biosca EG, Amaro C (1996) Toxic and enzymatic activities of Vibrio vulnificus biotype 2 with respect to host specificity. Appl Environ Microbiol 62:2331-2337

Bresnick EH, Dalman FC, Sanchez ER, Pratt WB (1989) Evidence that the $90 \mathrm{kDa}$ heat shock protein is necessary for the steroid binding conformation of the L cell glucocorticoid receptor. J Biol Chem 264:4992-4997

Burg MB, Kwon ED, Kültz D (1997) Regulation of gene expression by hypertonicity. Annu Rev Physiol 59:437-455

Cheng MY, Hartl FU, Martin J, Pollock RA and 5 others (1989) Mitochondrial heat shock protein hsp60 is essential for assembly of proteins imported into yeast mitochondria. Nature 337:620-625

Cho WJ, Cha SJ, Do JW, Choi JY and 7 others (1997) A novel 90-kDa stress protein induced in fish cells by fish rhabdovirus infection. Biochem Biophys Res Commun 233: 316-319

Cho WJ, Yoon WJ, Moon CH, Cha SJ and 6 others (2002) Molecular cloning of a novel chaperone-like protein induced by rhabdovirus infection with sequence similarity to the bacterial extracellular solute binding protein family 5 . J Biol Chem 277:41489-41496

Colorni A, Paperna I, Gordin H (1981) Bacterial infections in gilt head sea bream Sparus aurata cultured at Elat. Aquaculture 23:257-267

Conchas RF, Lemos ML, Barja JL, Toranzo AE (1991) Distribution of plasmid and chromosome mediated iron uptake system in Vibrio anguillarum strains of different origins. Appl Environ Microbiol 57:2956-2962

Crosa JH (1980) A plasmid associated with virulence in marine fish pathogen Vibrio anguillarum specifies an iron sequestering system. Nature 283:566-568

Crosa JH (1984) The relationship of plasmid mediated iron transport and bacteria virulence. Annu Rev Microbiol 38: 69-89

Deane EE, Li J, Woo NYS (2001) Hormonal status and phagocytic activity in sea bream infected with vibriosis. Comp Biochem Physiol 129B:687-693

Deane EE, Kelly SP, Luk JCY, Woo NYS (2002) Chronic salinity adaptation modulates hepatic heat shock protein and insulin-like growth factor I expression in black sea bream. Mar Biotechnol 4:193-205

DeNagel DC, Pierce SK (1993) Heat shock proteins in immune responses. Crit Rev Immunol 13:71-81

Egidus E (1987) Vibriosis: pathogenicity and pathology: a review. Aquaculture 67:15-28

Forsyth RB, Candido EPM, Babich SL, Iwama GK (1997) Stress protein expression in coho salmon with bacterial kidney disease. J Aquat Anim Health 9:18-25

Gething MJ, Sambrook J (1992) Protein folding in the cell. Nature 355:33-45

Green LE, Eisenberg E (1990) Dissociation of clathrin from coated vesicles by the uncoating ATPase. J Biol Chem 265: 6682-6687

Guzik K, Bzowska M, Dobrucki J, Pryjma J (1999) Heat shocked monocytes are resistant to Staphylococcus aureas-induced apoptotic DNA fragmentation due to expression of hsp72. Infect Immun 67:4216-4222

Harasewych MG, Adamkewicz SL, Blake JA, Suadek D, Spriggs T, Bolt CJ (1997) Phylogeny and relationship of pleuromarid gastropods (Mollusca: Gastropoda): an assessment based on partial 18s rRNA and cytochrome c oxidase sequences. Mol Mar Biol Biotechnol 6:1-20

Hjeltnes B, Roberts RJ (1993). Vibriosis. In: Inglis V, Roberts 
RJ, Bromage NR (eds) Bacterial diseases of fish. Cambridge University Press, Cambridge

Inamura H, Muroga K, Nakai T (1984) Toxicity of extracellular products of Vibrio anguillarum. Fish Pathol 19:89-96

Iwama GK, Thomas PT, Forsyth RB, Vijayan MM (1998) Heat shock protein expression in fish. Rev Fish Biol Fish 8: $35-56$

Jacquier-Sarlin MR, Fuller K. Dinh-Xuan AT. Richard MJ, Polla BS (1994) Protective effects of hsp70 in inflammation. Experentia 50:1031-1038

Kanemori Y, Nakai T, Muroga K (1987) The role of extracellular protease produced by Vibrio anguillarum. Fish Pathol 22:153-158

Kobayashi S, Welsh FA, (1995) Regional alterations of ATP and heat shock protein 72 mRNA following hypoxiaischemia in neonatal rat brain. J Cereb Blood Flow Metab 15:1047-1056

Kodama H, Moustafa M, Ishigura S, Mikami T, Izawa H (1984) Extracellular virulence factors of fish Vibrio: relationships between toxic material, haemolysins and proteolytic enzyme. Am J Vet Res 45:2203-2207

Kreger AS, Bernheimer AW, Etkin LA, Daniel LW (1987) Phospholipase D activity of Vibrio damsela cytolysin and its interaction with sheep erythrocytes. Infect Immun 55: 3209-3212

Laemmli UK (1970) Cleavage of structural proteins during the assembly of the head of bacteriophage T4. Nature 227: 680-683

Lee JY, Cho WJ, Do JW, Kim HJ and 5 others (1996) Monoclonal antibodies raised against infectious haematopoietic necrosis virus (IHNV) G protein and a cellular $90 \mathrm{kDa}$ protein neutralize IHNV infection in vitro. J Gen Virol 77 : 1731-1737

Lee KK (1995) Pathogenesis studies on Vibrio alginolyticus in the grouper, Epinephelus malabaricus, Bloch et Schneider. Microb Pathog 19:39-48

Lee KK, Yu SR, Liu PC (1997) Alkaline serine protease is an exotoxin of Vibrio alginolyticus in Kurama prawn, Penaeus japonicus. Curr Microbiol 34:110-117

Li J, Yie J, Foo RWT, Ling JML, Xu HS, Woo NYS (1999) Antibiotic resistance and plasmid profiles of vibrio isolates from cultured silver sea bream Sparus sarba. Mar Pollut Bull 39:245-249

Liu PC, Lee KK, Tu CC, Chen SN (1997) Purification and characterization of a cysteine protease produced by pathogenic luminous Vibrio harveyi. Curr Microbiol 35:32-39

Liu PV (1957) Survey of hemolysin production among species of pseudomonads. J Bacteriol 74:718-727

Lowry OH, Rosenbrough NJ, Farr AL, Randall RJ (1951) Protein measurement with Folin phenol reagent. J Biol Chem 193:265-273

Martin J, Horwich A, Hartl U (1992) Prevention of protein denaturation under heat stress by the chaperone hsp60. Science 258:995-998

Martinez J, Perrez-Serrano J, Bernadina WE, Rodriguez Caabeiro F (1999a) Influence of parasitization by Trichinella spiralis on the levels of heat shock proteins in rat

Editorial responsibility: David Bruno,

Aberdeen, UK liver and muscle. Parasitology 118:201-209

Martinez J, Perrez-Serrano J, Bernadina WE, Rodriguez Caabeiro F (1999b) Shock response induced in rat brain and spleen during primary infection with Trichenella spiralis larvae. Parasitology 118:605-613

Mestril R, Chi SH, Sayen R, Dillmann WH ( 1994) Isolation of a novel inducible rat heat shock protein (hsp70) gene and its expression during ischemia/hypoxia and heat shock. Biochem J 298:561-569

Ostermann J, Horwich AL, Neupert W, Hartl FU (1989) Protein folding in mitochondria requires complex formation with hsp60 and ATP hydrolysis. Nature 341:125-130

Perez MJ, Rodriguez LA, Nieto TP (1998) The acetylcholinesterase ichthyotoxin is a common component in the extracellular products of Vibrionaceae strains. J Appl Microbiol 184:47-52

Picard D, Khursheed B, Garabedian MJ, Fortin MG, Lindquist S, Yamamoto KR (1990) Reduced levels of hsp90 compromise steroid receptor action in vivo. Nature 348:166-169

Pratt WB (1997) The role of the hsp90 based chaperone system in signal transduction by nuclear receptors and receptor signalling via map kinase. Annu Rev Pharmacol Toxicol 37:297-326

Ryan JA, Hightower LE (1996) Stress proteins as molecular biomarkers for environmental toxicology. In: Feige U, Morimoto RI, Yahara I, Polla B (eds) Stress inducible cellular responses. Birkhäuser Verlag, Basel

Smith DF, Toft DO (1993) Steroid receptors and their associated proteins. Mol Endocrinol 7:4-11

Sudheesh PS, Xu HS (2001) Pathogenicity of Vibrio parahaemolyticus in tiger prawn Penaeus monodon Fabricus: possible role of extracellular proteases. Aquaculture 196: $37-46$

Toranzo AE, Barja JL (1993) Virulence factors of bacteria pathogenic for coldwater fish. Annu Rev Fish Dis 3:5-36

Toranzo AE, Barja JL, Colwell RR, Hetrick FM, Crosa JH (1983) Haemagglutinating, haemolytic and cytotoxic activities of Vibrio anguillarum and related vibrios isolated from striped bass on the Atlantic coast. FEMS Microbiol 18:257-262

Ungewickell E (1985) The $70 \mathrm{kDa}$ mammalian heat shock proteins are structurally and functionally related to the uncoating protein that releases clathrin triskelia from coated vesicles. EMBO J 4:3385-3391

Wang XH, Leung KY (2000) Biochemical characterization of different types of adherence of Vibrio species to fish epithelial cells. Microbiology 146:989-998

Wang XH, Oon HL, Ho GWP, Wong WSF, Lim TM, Leung KY (1998) Internalization and cytotoxicity are important virulence mechanisms in vibrio-fish epithelial cell interactions. Microbiology 144:2987-3002

Woo NYS, Kelly SP, (1995) Effects of salinity and nutritional status on growth and metabolism of Sparus sarba in a closed seawater system. Aquaculture 135:229-238

Yancey PH, Clark ME, Hand SC, Bowlus RD, Somero G (1982) Living with water stress: evolution of osmolyte systems. Science 217:1214-1222

Submitted: November 6, 2003; Accepted: June 28, 2004

Proofs received from author(s): November 8, 2004 